Article

\title{
The Caribbean's Geotourism Potential and Challenges: A Focus on Two Islands in the Region
}

\author{
Colmore S. Christian
}

Biological and Environmental Sciences Department, College of Agricultural, Life and Natural Sciences, Alabama A\&M University, Normal, AL 35762, USA; colmore.christian@aamu.edu; Tel.: +256-372-4335

Received: 21 May 2018; Accepted: 20 July 2018; Published: 26 July 2018

\begin{abstract}
Geotourism is a relatively new concept in the tourism industry, a concept which apparently has not yet been formally embraced by Caribbean destinations. This paper, based primarily on a literature review supplemented by the first-hand knowledge of the author, who served for over a decade in the natural resource management and tourism sectors in the region, identifies some of the geotourism assets and assesses the geotourism potential of two selected Caribbean islands, namely the Commonwealth of Dominica and St. Lucia. Indications are that the islands of the region have outstanding geological formations, dormant and active volcanic zones and associated geomorphological features, and breath-taking terrestrial and marine landscapes, including deep river gorges and tall mountains, and beautiful beaches, which together constitute important geotourism assets. Currently, these resources are marketed and promoted as part of the region's nature tourism attractions. The feasibility of incorporating geotourism as a component of this overall nature tourism thrust is explored in this paper. As a follow-up to this study a survey of tourism officials, natural resource professionals, and selected scientists of the region is proposed for the purpose of identifying the reasons and constraints preventing the Caribbean region from formally embracing geotourism, developing and promoting the geotourism resources of the region as a unique component of the overall tourism product.
\end{abstract}

Keywords: geotourism; sustainable tourism; geoheritage; volcanic origin; sulphur springs; Boiling Lake; natural hazards; Caribbean islands; Dominica; St. Lucia

\section{Introduction}

There is a diversity and abundance of geological, volcanic, geomorphological, and seismic sites distributed throughout the Caribbean archipelago. For decades, these natural sites have captured the interest and imagination of residents and have captivated the attention and curiosity of visitors to the region. Consequently, although these sites have neither been formally identified as geotourism assets nor marketed and promoted as such by regional tourism authorities, many of these sites currently form the basis of the 'nature tourism' thrust in the region. One can therefore logically conclude that in these circumstances some form of 'geotourism' has been occurring in the Caribbean for some time under other names, such as ecotourism, sustainable tourism, and nature tourism.

Some of the region's nature-based tourism assets are vulnerable to the storms, hurricanes and other natural events which annually affect the region. For example, on 18 September 2017, Hurricane Maria 'navigated' through and caused extensive damage to the natural resources and infrastructure in many islands of the Caribbean including the Commonwealth of Puerto Rico and the Commonwealth of Dominica, hereafter referred to as Puerto Rico and Dominica respectively. A few days earlier, on 6 September, to be exact, Hurricane Irma, which maintained hurricane-strength winds from 31 August until 11 September 2017, had followed a similar destructive path through the Caribbean after impacting at least nine states on the US mainland [1]. Islands such as Antigua's sister island of 
Barbuda, St. Martin/St. Maarten, the US Virgin Islands, Puerto Rico, and the British Virgin Islands suffered the brunt of Hurricane Irma's furry, one of the strongest Atlantic basin hurricanes ever recorded [1]. Hurricane Maria was the strongest hurricane to impact Dominica in recent history.

Hurricanes Irma and Maria, both of which were category 5 storms, tore through and mangled the islands' infrastructure, turned streets into rivers, ripped down power lines, cut off access to some communities, toppled trees and defoliated those left standing, blew away groundcover vegetation, destroyed agricultural crops, and decimated wildlife. Dominica, which was commonly referred to as 'The Nature Island of the Caribbean' prior to the passage of Hurricane Maria, was 'naked' in the days and weeks immediately following the passage of the hurricane. Fortunately, although natural forces can be very destructive, similarly, nature has a way of healing itself. Whereas the natural restoration process is generally much slower than the destructive phase, the Government, natural resource professionals, and the people of Dominica were very pleased and encouraged when evidence of natural revegetation of the hills and mountains became evident. Six months after Hurricane Maria in September 2017, a fair amount of the vegetation had been restored on the landscape.

The Caribbean region (Figure 1) not only lost much infrastructure and natural resources as a result of the hurricanes, the region also lost one of its primary socio-economic life lines, the tourism industry. It has been noted that the last global financial crisis created " . . an opportunity for innovation in management and the emergence of new tourism products in tourism marketing" [2]. Similarly, although there is no doubt that the hurricanes of 2017 negatively affected tourism marketing and tourism services of the Caribbean, the destruction may have presented the region with an opportunity for some level of innovation and creativity in the tourism sector. Geotourism, a relatively new concept, could be one such possible option.

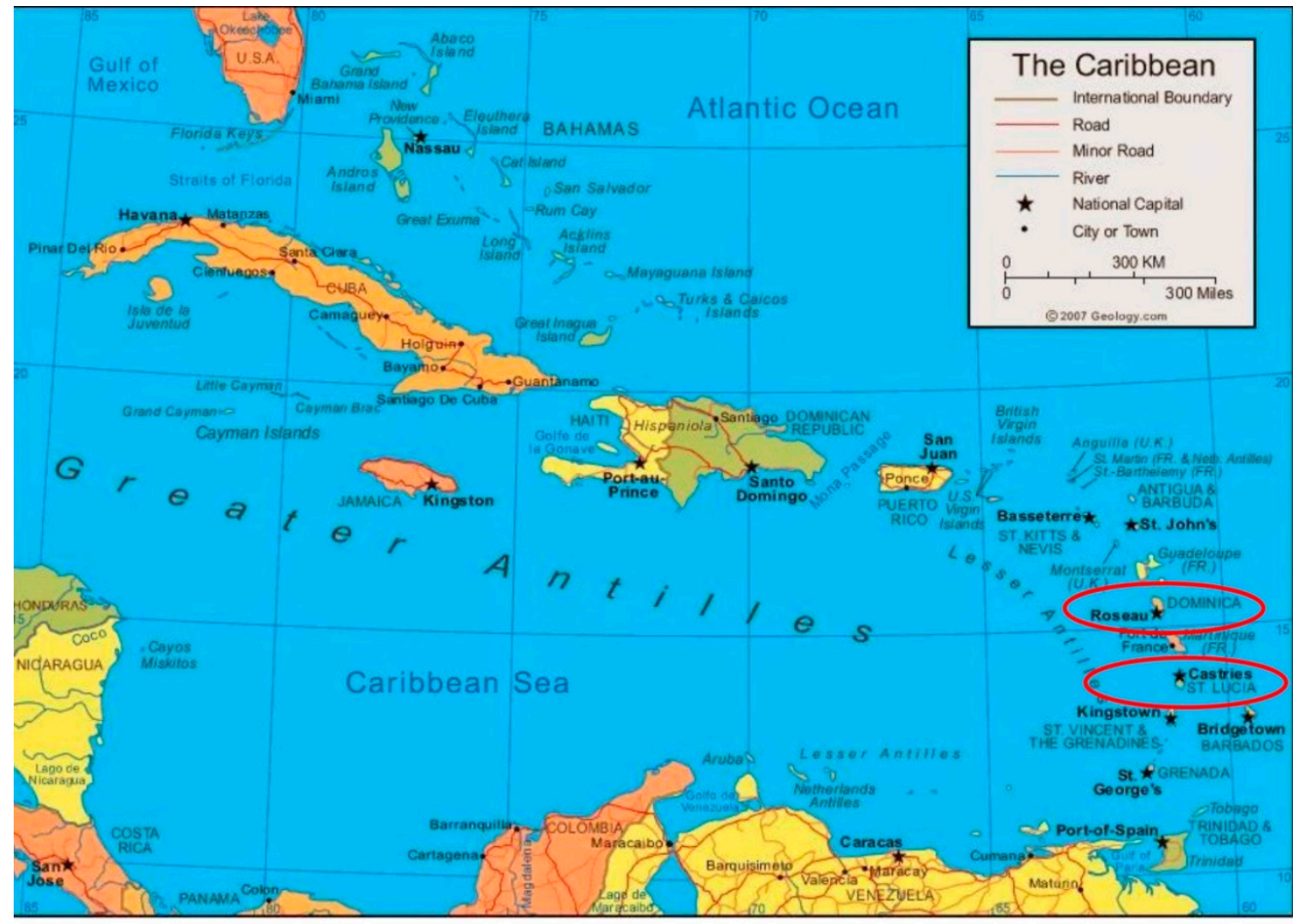

Figure 1. Map of the Insular Caribbean with the two case-study countries of Dominica and St. Lucia identified. 
The insular Caribbean is the most popular warm-weather tourism destination [3], with tourism earnings accounting for $25 \%$ of the region's gross domestic product [4]. Overall, there has been a small annual increase in the number of tourists to the Organization of Eastern Caribbean States (OECS) sub-region over the five years immediately preceding Hurricanes Irma and Maria (Table 1).

Table 1. The tourism arrival trends in the Independent Member States of the Organization of Eastern Caribbean Sates (OECS) during the period 2010-2015. Countries are ranked based on 2013 and 2014 arrival data (source: CTO, [5]).

\begin{tabular}{ccccccc}
\hline \multirow{2}{*}{ Country } & \multicolumn{5}{c}{ Tourism Arrival Figures Per Year (\% Change) } \\
\cline { 2 - 6 } & $\mathbf{2 0 1 0}$ & $\mathbf{2 0 1 1}$ & $\mathbf{2 0 1 2}$ & $\mathbf{2 0 1 3}$ & $\mathbf{2 0 1 4}$ & 2015 January-May \\
\hline St. Lucia & 305,937 & 312,404 & 306,801 & 318,626 & 338,158 & 185,424 \\
Antigua \& Barbuda & 229,943 & 241,331 & 246,926 & 243,932 & 249,316 & 116,570 \\
Grenada & 110,471 & 118,295 & 112,307 & 116,456 & 133,521 & 38,000 \\
St. Kitts \& Nevis & N/A & N/A & N/A & 100,997 & 104,730 & N/A \\
Dominica & 76,517 & 75,546 & 78,119 & 78,277 & 81,472 & 33,332 \\
St. Vincent \& Grenadines & 72,478 & 73,866 & 74,364 & 71,725 & 70,713 & 25,927 \\
\hline
\end{tabular}

Many policy makers, tourism officials, tour operators, natural resource professionals, and residents of tourism destinations have accepted the concept of sustainable tourism and actively seek to advance that concept. Sustainable tourism is "Tourism that takes full account of its current and future economic, social and environmental impacts, addressing the needs of visitors, the industry, the environment and host communities" [6]. The sustainable tourism concept has been pursued through different frameworks, including nature tourism, ecotourism, cultural tourism, indigenous tourism, agri-tourism, heritage tourism, and community tourism. More recently, geotourism has been added to the mix of sustainable tourism approaches. The common principles across these sustainable tourism frameworks are the respect for the resource base and the environment as well as for the host country and local residents, while providing meaningful and rewarding visitor experiences.

Geotourism is a concept for which two slightly different definitions and emphasis areas, namely 'geological' or 'geographical', have been advanced [7]. "Geotourism is essentially 'geological tourism'. The geological element focuses on geology and landscape and includes both 'form', such as landforms, rock outcrops, rock types, sediments, soils and crystals, and 'process', such as volcanism, erosion, glaciation, etc. The geotourism approach seeks to facilitate tourists visiting, learning from, appreciating and engaging in geosites" [8]. The National Geographic Society, however, has defined geotourism " ... as tourism that sustains or enhances the distinctive geographical character of a place-its environment, heritage, aesthetics, culture, and the well-being of its residents" [9]. Although these definitions are not mutually exclusive, it is evident that the former definition focuses on the 'geological assets', whereas the latter definition emphasizes the 'geographical assets'. The emphasis areas of both definitions are embraced in this exploratory study. Based on these definitions some of the islands of the Caribbean are obviously blessed with outstanding and unique geotourism assets. However, although the Caribbean " ... is increasingly challenged not only to maintain its share of the global tourism market, but also to re-define and diversify its tourist product" [4], indications are that the regional authorities are yet to formally identify and develop available geoheritage sites. Furthermore, geotourism has not yet been embraced as tourism 'branding' or 'marketing' approaches by the region.

This paper seeks to identify and briefly describe the OECS sub-region's primary geotourism assets, presents a framework for a regional geotourism development strategy, discusses the tourism potential of these assets, and proposes marketing and promotional strategies to differentiate these assets and opportunities in the market place. The analysis will be primarily concentrated on the selected states of Dominica and St. Lucia, two of the independent member-states of the OECS. These islands, where in addition to English a French-based creole is spoken, were selected because their topography, geology, 
historical background, and natural asset-base are very similar. Unlike Migon and Pijet-Migon [10] who referenced the different classifications of geosites, no attempt has been made in this paper to differentiate among the different geosites found in the region.

\section{Materials and Methods}

The geotourism assets and the geotourism potential of Caribbean destinations, particularly two independent islands (Dominica and St. Lucia) of the Eastern Caribbean, have been identified, described and discussed. The assessment is based primarily on a literature review supplemented by the first-hand knowledge of the author, who served for over a decade in the natural resource management and tourism sectors in the region. Consequently, the geotourism assets identified and discussed in this paper were influenced by literature findings and personal knowledge. The assessment, analysis, and results are presented in the context of the OECS sub-region.

\section{Results}

\subsection{Tourism in the OECS Sub-Region}

All the islands in the OECS, some islands more so than others, are actively pursuing tourism as an economic development strategy. These islands have made significant investments in infrastructural developments such as expansion of airports, seaports, and road networks, as well as in service skills enhancement, human capacity development, and marketing and promotion in support of the tourism sector. Historically, the sub-region's tourism has revolved around its natural resources (e.g., flora, fauna, beaches, wetlands, etc.), cultural resources (e.g., cuisine, carnivals and festivals, music, crafts, indigenous groups, etc.), and historical resources (e.g., ruins of fortifications, sunken ships, etc.). Prior to the passage of Hurricane Maria, for example, Dominica, in comparison to the other islands, had a rich variety and quantity of natural assets. The island, the most mountainous in the Lesser Antilles [11], was known as having a total of 175 recorded bird species, which included two endangered and endemic parrot species the Sisserou or Imperial Parrot (Amazona imperialis) and the Red-necked Parrot (Amazona arausiaca) [12], two crater fresh water lakes, a boiling lake, a variety of plant species, some of which are rare and/or endemic to the island, one of the best marine diving sites, and the only island in the sub-region with a National trail which traverses different vegetation zones, including relatively pristine tracts of rainforest.

The geographic landscape of the Kalinago Territory, home to the indigenous Carib or Kalinago people, is an import component of Dominica's tourism assets. The traditional buildings, the crafts, artisan knowledge and skills of these people attract many visitors.

The islands of Antigua and Barbuda, Grenada, St. Lucia, and St. Kitts and Nevis all attract more tourists annually than Dominica, although their 'environmental infrastructure' is less abundant and diverse than Dominica's. The country of St. Vincent and the Grenadines attracts the least number of tourists among the group (Table 1). In comparison to Dominica, these islands have international airports and better visitor accommodation facilities, hence being able to attract and host more visitors. These islands, however, all have some unique and outstanding features. St. Lucia's well-known Pitons and its endemic St. Lucian parrot (Amazona versicolor), St. Vincent and the Grenadines' endemic parrot (Amazona guildingii) and Sulphur Springs, and the seismic area around High Peak of Nevis and the ruins of Brimstone Hills, an old fort, on St. Kitts illustrate the diversity of the region's historical and natural assets.

Huang and Sarigollou [4] identified four segments of visitors to the Caribbean-'Sun \& Fun Seekers', 'Active Sportspeople', 'Variety Seekers' and 'Sightseers'. Their analysis suggests that the interests of the 'Variety Seekers' and the 'Sightseers' are more amenable and aligned to exploration of geotourism sites in the region. It can be concluded, then, that a large percentage of the tourists to the sub-region visit primarily because of their interest in ecotourism. On a few of the islands, such as St. Vincent and the Grenadines, St. Lucia, St. Kitts and Nevis, Montserrat, and Dominica, visitors 
may also choose to explore the geological, seismic sites, fumarolic assets of the islands. It should be noted, however, that in addition to the islands listed in the foregoing, other islands in the Caribbean archipelago such as Antigua and Barbuda, Martinique, Haiti, Dominican Republic, and Trinidad and Tobago do experience seismic activities from time to time [13]. Some of these seismic activities are sometimes sufficiently strong to result in loss of human life, as well as causing damage to man-made infrastructure and to the environmental infrastructure as defined by Cumming et al. [14].

Historically, the resulting geological and geographical transformational changes in the landscape in the aftermath of catastrophic seismic activities such as earthquakes and volcanic eruptions have served as 'major draws' for tourists. This has been the experience in the Caribbean, for example, in Montserrat following the 1995 volcanic eruption, on Martinique after eruptions of Mt. Pelee in 1902 and 1929 [15], as well as in other regions of the world. For example, in Hawaii following the destruction caused by the major eruptions of the Kilauea Volcano, which has continued to erupt since 1983, and in Washington State following the eruption of the Mt. St. Helen volcano in 1987.

\subsection{Dominica's Possible Geotourism Assets and Opportunities}

Whereas from an overall tourism development perspective, Dominica has many challenges and weaknesses, from the tourism asset perspective, the island is very blessed with a diverse mix of natural and cultural assets relative to the size of the island. These natural assets, categorized as 'ecological infrastructure' based on the Cumming et al. [14] classification, provide a range of ecosystem services to the country and form the backbone of the island's nature tourism thrust. Some of these assets are geotourism resources, sufficient in diversity and geographic distribution on the island to support a geotourism sub-sector. For the purposes of this analysis, four of Dominica's primary sites with great potential for geotourism have been identified and discussed.

\subsubsection{The Boiling Lake and Valley of Desolation}

The Boiling Lake and Valley of Desolation region, located in the interior of the island, is a vivid reminder of Dominica's volcanic origin. Lang [16] stated that virtually the whole of Dominica is volcanic. By any definition there are dramatic examples of volcanic activities in the Boiling Lake and Valley of Desolation of Dominica. There have been two steam explosions (phreatic activity) in the Valley of Desolation, in 1880 and 1997 [15]. The Boiling Lake, which is approximately 0.2 ha in area, is regarded as the second-largest such lake in the world, with the temperature along the edges ranging between $82^{\circ} \mathrm{C}$ and $91.5^{\circ} \mathrm{C}$ [17].

Although the three-and-a-half-hour trek from the main parking lot to the Boiling Lake is extremely challenging and physically demanding, a fair percentage of visitors to the island navigate the steep climbs and deep valleys, river crossings, and narrow trails to visit the Boiling Lake and Valley of Desolation. Truly, the view from the edge of the Boiling Lake, the sulphur fumes and steam rising from the Lake together with the smell of 'nature's elements' give one a sense of accomplishment after the long hike. During the cautious walk through the Valley of Desolation on the way to the Boiling Lake, sights of the bubbling mud holes, the hot water streams of varying shades of yellow, white and dark blue stream bed backgrounds, supplemented by the sparse but uniquely adapted vegetation seen along the way, and the 'therapeutic smell of sulphur' are special memories to be cherished by all first-time visitors to the Boiling Lake.

Enjoyment of the beautiful but somewhat frightening landscape of deep valleys and steep mountain ridges along the route to the Boiling Lake and Valley of Desolation, admiration of the different plant species such as tree fern (Cyathea spp. and Hemitelia spp.), the Bwa Bande tree (Richeria grandis) which is said to have aphrodisiac properties, or the beautiful Heliconia (Heliconia bihai and Heliconia caribaea) are indeed very incredible and rewarding experiences for the determined hiker. Hearing the pleasant and melodious sound of inimitable wildlife species such as the Mountain Whistler (Mydestes genibarbis) and the possible sighting of a Red Necked Parrot (Amazona arausiaca) are additional encouraging and inspiring motivators along the way. The transition from rainforest 
vegetation zone to cloud forest (or elfin woodlands), and to the fumarole vegetation zone in the Valley of Desolation adds to the visitors' experience, satisfaction, and knowledge base.

The Titou Gorge, located at the entrance of the main trail to the Boiling Lake and Valley of Desolation, is somewhat trapezoid in shape in some parts. The Titou Gorge is a narrow (estimated $3.04 \mathrm{~m}$ across) section of a stream flowing through a rocky zone. Much of the water in the Gorge emanates from underground. Posted signs inform visitors that only efficient swimmers should venture swimming in the Gorge because of the currents and water's depth. Many visitors to the Boiling Lake stop at the Titou Gorge on their return trip for a swim and to wash away sweat and grime, as well as to sooth their aching feet and muscles. The few small warm water springs which feed into the Titou Gorge make the Gorge even more inviting to visitors, particularly after a long hike.

Visits to the Boiling Lake and Valley of Desolation region are, to some degree, very satisfying, considering the fact that the region is within the boundaries of the island's first national park, the Morne Trios Pitons National Park. The Park, established in 1975, was listed as a World Heritage Site- the Eastern Caribbean's first World Heritage Site in the natural areas category-by the United Nations Scientific Organization (UNESCO) in December 1997 [18]. At the time of consideration of the Park's nomination, the World Heritage Committee stated that the Morne Trois Pitons National Park was being inscribed " $\ldots$ on the basis of natural criteria (viii) and $(x)$ for its diverse flora with endemic species of vascular plants, its volcanoes, rivers and waterfalls, illustrating ongoing geo-morphological processes with high scientific value" [18].

\subsubsection{Layou River Gorge}

The westward-flowing Layou River, once regarded as the widest river on the island, empties into the Caribbean Sea. The Layou River and many of its tributaries emanate in the island's Central Forest Reserve, the first legally protected forest area established on the island. The Layou River meanders its way from the interior towards the coast. The River flows through the magnificent Layou River Gorge, which is reminiscent to some degree of parts the Grand Canyon National Park in the United States. Surely, the Layou River Gorge is no comparison to the vast geological landscape of the Grand Canyon. However, the banks of the River in some parts are estimated to be more than $305 \mathrm{~m}$ above the water level.

In 1997, the regular flow of the Layou River was significantly reduced as a result of a series of rock landslides which blocked the normal river flow [19]. The water level in this 'natural dam' gradually increased over a period of several months to form what became known as the Mathieu Dam. The Dam eventually collapsed one afternoon, sending thousands of cubic meters of a water, sand, silt and debris mixture crashing down the valley, destroying roads, bridges, and other structures in its path. Although no human life was lost, the landscape of the lower sections of the River was forever changed. The River is neither as wide nor as deep as it was prior to the Dam's collapse, because of the regular silt and sand build-up on the river bed whenever it rains up-river. In 2011, the Dam collapsed twice, again resulting in major flooding [19]. The threat of flooding from the Dam has not yet been entirely eliminated.

Prior to the major rock slide, a hotel—the Layou River Hotel—was located on the northwestern bank of the River. The Hotel was seriously impacted by the flow from the broken dam. In spite of reduced water levels, water volume, and water clarity at the lower section of the River, that section is currently used for tourism-related river-tubing. Many visitors experience river-tubing down the River as part of their ecotourism experience.

\subsubsection{The Trafalgar Falls/Wotten Waven Region}

Two of the island's more popular and easily accessible tourism sites are Trafalgar Falls and Wotten Waven Sulphur Springs. The less popular 46-61 m tall Middleham Falls, though not as accessible as the Trafalgar Falls, are attractive in their own right, but are less visited. Both Trafalgar Falls and Middleham Falls are included in the island's ecotourism sites designation, for which an access pass must be purchased by non-nationals and non-residents wishing to visit those sites. 
Two adjacent waterfalls make-up the Trafalgar Falls. The taller of the twin Falls cascades down the surface of an estimated 45.7-m-tall rock-face, whereas the shorter Fall, which seems to have a larger volume of flow, tumbles from the ridge top vertically down to the base of the Fall. Although posted signs warn persons against going to the base of the Falls, some visitors risk personal injury and navigate the large and slippery rocks to the base of the taller of the twin Falls, primarily to enjoy a bath and some relaxation in the warm water springs at that location.

Wotten Waven, a community adjacent to the village of Trafalgar, is well known for the large number of easily accessible hot springs, sulphur vents, fumaroles, and bubbling mud holes scattered on private property throughout this rural community. These resources have stimulated a few small nature-based enterprises. A couple of community residents have harnessed the warm springs into man-made pools and provided changing rooms, for which both visitors and nationals pay for use. Research suggests that compounds which contain sulphur are usually helpful for controlling joint- and skin-related ailments and blemishes [20]. Such health benefits are among the intangible ecosystem services realized from nature [21]. Wotten Waven residents have capitalized on these 'perceived medicinal benefits' and have been packaging and selling 'sulphur-laden mud' from the bubbling mud-holes to visitors for treating skin diseases.

The Middleham Falls are within the Morne Trois Pitons National Parks and World Heritage Site, but Trafalgar Falls and Wotten Waven Hot Springs are not within the boundaries of units of the National Park System.

\subsubsection{The Soufriere/Scotts Head Region}

The Soufriere/Scotts Head region is another location on the island with much geotourism potential. Sulphur steam vents, bubbling mud-holes and hot water streams are found at the Soufriere Sulphur Springs location. The Soufriere Sulphur Springs area has been designated as one of the ecotourism sites for which access passes must be purchased in advance. Pools to facilitate the enjoyment of warm water baths and an environmental interpretation center have been constructed for visitors' use. The vegetation and other resources of the area in the immediate vicinity of the sulphur vents and bubbling mud-holes are somewhat similar to those found in the Valley of Desolation. The Soufriere Sulphur Springs area is part of a former agricultural plantation.

Overall, the Soufriere/Scotts Head bay is an ancient, spectacular, submerged volcanic crater. "Dramatic rock walls and pinnacles dominate the undersea landscape and the area is further enlivened with archways, caves ... " [22]. There is a small warm water pool along the Soufriere beach. One of the most interesting potential geotourism sites in the Soufriere coastal region, however, is the popular scuba diving spot called 'Champagne'. The stream of warm, continuous 'champagne-like' bubbles which rise from the seabed through the water column is very soothing and attracts some special marine species, making the area very popular with scuba divers, locals and visitors alike. Evans [23] indicates that the area is approximately $27.9 \mathrm{~m}^{2}$ in area at a depth of $3.05 \mathrm{~m}$.

Soufriere and Scotts Head are adjacent southern communities. The distance from the village of Soufriere to the Scotts Head point, the southern-most tip of the island, is approximately $3.22 \mathrm{~km}$. The ruins of an 18th century garrison are evident on the Scott Head point. There are very few trees on the Scotts Head point, which is approximately $91.5 \mathrm{~m}$ above sea level. Consequently, visitors to that point have an unobstructed line of sight of the island's Southwest coast. The breaking of the waves from the Atlantic Ocean on the southeastern side and the gentle noise of the calmer Caribbean Sea on the southwestern side make for a rewarding experience for visitors to the Scotts Head peninsular.

\subsection{St. Lucia's Potential Geotourism Assets and Opportunities}

St. Lucia has developed a strong tourism sector, primarily based on nature tourism. Some of the island's best-known nature tourism assets are its beaches, waterfalls, The Pitons, and Soufriere area. These assets are 'geological' in nature, but do have some 'geographical' scope. 
Many North American and European tourists are attracted to long stretches of white sandy beaches, an asset which is readily available on St. Lucia. The island does have a few black sandy beaches, the result of erosion of volcanic rocks on the island.

\subsubsection{The Pitons}

The Pitons, one of St. Lucia's national treasures and the island's most famous landmark, are located near the town of Soufriere. These primeval twin peaks, The Gros Piton $(771 \mathrm{~m})$ and The Petit Piton $(743 \mathrm{~m})$ are evidence of the volcanic history of the island. In 2004 The Pitons Management Area (PMA), 2909 ha in area $60 \%$ of which is marine, was inscribed by UNESCO on the World Heritage List, in the natural areas category [24]. The flora and fauna of the PMA include over 150 plants species, 168 species of finfish, 74 species of cnidaria, including corals, eight molluscs, 14 sponges, 15 arthropods, 27 bird species (five of them endemic), three indigenous rodents, one opossum, three bats, eight reptiles and three amphibians [24]. Sulphurous fumaroles and hot springs are found within the PMA. Hiking the Pitons, particularly the Gros Piton, is very popular with locals and visitors alike. However, the Petit Piton is more challenging, and consequently only daring climbers and skilled hikers have succeeded in climbing to the summit.

\subsubsection{The Soufriere Volcano or Sulphur Springs}

In close proximity to The Pitons is the Soufriere Volcano, also referred to as the Sulphur Springs. Now dormant, it is the world's only drive-in volcano. The steamy Sulphur Springs offer a direct and fascinating lesson about the origins and geology of the Caribbean Rim. The mud baths at the Sulphur Springs are very popular with visitors, because such a bath 'detoxifies the body and helps heal sun burns, eczema, arthritis, sore joints, and other aliments'. These reported health benefits are supported by scientific advances and the acceptance of medical geological research and geoscience tools [25]. According to Finkelman [25], the therapeutic benefits of naturally occurring mineral waters, mud and sand, though not well known in the United States, are used by medical practitioners to treat a wide range of conditions in Europe and Japan.

In outdoor settings, resource managers generally present more than one interpretive theme to visitors. Thus, although the potential geotourism sites identified both in Dominica and St. Lucia have been developed and are currently managed as ecotourism sites, given the spectacular geoheritage resources of these sites, a geotourism-focused interpretive theme could also be introduced and presented at these sites. To accomplish this objective, greater emphasis will have to be placed on the volcanic, seismic, and geological features of the sites. In this regard in addition to any guided tours which may be offered, the posting of well-designed and informative signage and interpretive panels for the benefit of the public would be useful. Other initiatives are captured below.

\section{Discussion and Future Outlook}

If we accept the premise that the focus of geotourism is on 'geological', 'geomorphological', 'geography' and 'overall landscape' features, there is no doubt that the Caribbean region, and the OECS sub-region in particular, has the resource base to support geotourism. In the two OECS member states-Dominica and St. Lucia-considered in this study, several such resources have been identified (Table 2). Based on this premise, coupled with the fact that the Caribbean is very dependent on tourism as a development strategy, the Governments of the region would be well advised to consider and initiate steps to capitalize on the full potential and opportunities of these assets.

Successful geotourism development will require some national planning and preparation. As a first step, it would be useful if the governments of the region were to commission a rapid assessment survey to identify and compile an inventory of the geotourism assets in each destination. Formulation of a national policy to lay the foundation for future actions should be actively pursued. This policy should provide for the participation and involvement of all stakeholders and ultimately 
endorsed at the highest national level. The proposed policy must outline a clear mission and vision, as well as set SMART objectives.

Table 2. Summary of the categorization of the geotourism resources identified in the OECS states of Dominica and St. Lucia, which are examined in this study.

\begin{tabular}{ccccc}
\hline \multirow{2}{*}{ Potential Geotourism Assets } & \multicolumn{2}{c}{ Category } & \multicolumn{2}{c}{ Country } \\
\cline { 2 - 5 } & Geological & Geographical & Dominica & St. Lucia \\
\hline Boiling Lake and Valley of Desolation & Yes & Yes & Yes & No \\
Sulphur Vents/Fumaroles/Mud Holes & Yes & Yes & Yes & Yes \\
Seismic Zones & Yes & No & Yes & Yes \\
Water Falls & Yes & Yes & Yes & Yes \\
Warm Water Springs & Yes & No & Yes & Yes \\
Mud Baths/Sulphur-laden Mud & Yes & No & Yes & Yes \\
River Gorges & Yes & Yes & Yes & Yes \\
Beaches (White and Black Sands) & Yes & Yes & Yes & Yes \\
Unique Mountains (Tall/Well-known) & Yes & Yes & Yes & Yes \\
Outstanding Landscapes & Yes & Yes & Yes & Yes \\
\hline
\end{tabular}

A mix of strategic approaches will have to be undertaken in an effort to accomplish any successful and integrated geotourism program in the region. Discussions, through regional workshops and conferences, as well as at regional political forums, of geotourism initiatives would be helpful in crafting a road-map for the development and promotion of this relatively new tourism concept in the region. In this regard, the appointment of an OECS or CTO Geotourism Working Group and the scheduling of a special session on the subject at the CTO's Annual Sustainable Conference would help to ensure that the matter receives the regional or sub-regional attention it deserves.

A well-structured and organized research and monitoring program will have to be instituted early in any proposed geotourism program, in order to ensure that the integrity of and respect for the environment and important elements of the sustainable tourism concept are upheld. Research and monitoring programs should not only be directed towards environmental protection and monitoring, but very importantly, the program should seek to gauge and determine the demand for geotourism at the national and sub-regional levels. Such determination will help to inform future strategies and investments in any geotourism sub-sector.

Of course, the proposed research and monitoring program should assess ecological and social impacts and their possible implications. Historically, the Caribbean has lost much coastal vegetation such as mangrove to make way for hotels, marinas and tourism support services. Loss of coastal vegetation contributes to beach erosion. The unmanaged disposal of sewage and solid waste, and the pollution of water bodies negatively impact the health of ecosystems and the quality of the ecosystem services they provide. Every effort should be made to ensure that geotourism does not result in any significant ecological impacts in the region.

Geotourism is a vehicle which can be used to promote geoconservation and an understanding of geological heritage [7]. The Caribbean's geotourism strategic mix, therefore, should address the special training needs of tour guides in geology, seismology, geography, related history, and visitor safety, in addition to reinforcement of flora and fauna basics. The need for development of a comprehensive search and rescue plan which provides for clear lines of communication and required partnerships will be necessary in each destination.

Unless the potential geotourism visitor is sensitized to and informed about the opportunities in the sub-region, the anticipated benefits to the sub-region will not be realized. Therefore, a well-organized and funded marketing program will be essential for development of a sustainable geotourism program in the region. Critical to the success of geotourism marketing is branding. Branding " ... is one of the most important aspects of any business, large or small. An effective brand strategy can provide 
a major edge in increasingly competitive markets [26]. Branding should be considered and factored into the region's tourism marketing and promotion campaigns.

Dominica's Morne Trios Pitons National Park and St. Lucia's Pitons Management Area have been listed as World Heritage Sites [18]. UNESCO reserves the World Heritage Site-Natural Area category designation for sites which contain resources and landscapes of global significance. UNESCO has adopted a similar approach in advancing its Global Geopark concept. "Global Geoparks are single, unified geographical areas where sites and landscapes of international geological significance are managed with a holistic concept of protection, education and sustainable development" [27]. A UNESCO Global Geopark uses its geological heritage, in connection with all other aspects of the area's natural and cultural heritage, to enhance awareness and understanding of key issues facing society, such as using our earth's resources sustainably, mitigating the effects of climate change and reducing natural disasters-related risks [27].

Against this background, some of the Caribbean islands may wish to explore the nomination of some of primary sites such as Dominica's Boiling Lake and Valley of Desolation and Layou River Gorge and St. Lucia's famous Pitons, among others, as Geoparks. The fact that Geoparks are normally established with the involvement and participation of all relevant local and regional stakeholders and authorities in the area will ensure that strong partnerships are fostered from the outset. This partnership approach will ultimately provide the environment for the realization of " ... communities' goals while showcasing and protecting the area's geological heritage" [27]. The marketing and promotion of 'tourism products' such as World Heritage Sites and Geoparks which have been accepted by the international agencies will add credence to the efforts of the sub-region and likely to help attract more nature tourists and geotourists in particular.

For more targeted and effective use of limited funds available for tourism marketing and promotion, it would be advisable that efforts are focused. To accomplish this, it would be important that an analysis of the segmentation of the tourism sector: scuba divers, birders, hikers, cultural tourists, and geotourists be undertaken.

The pursuit of geotourism presents another avenue for building community capital and development of cohesive partnerships at the community level, for establishment of new small business ventures, and stimulation of new areas of skills development and training, and pursuit of the shared vison of protecting and promoting the sub-region's geological processes, features, historical themes linked to geology, or outstanding landscapes and geological beauty [27].

The Caribbean has fallen behind the other regions of the world, not only with respect to the development and promotion of geotourism, but also with respect to the establishment of Geoparks and Geopark networks. As Miller et al. [28] have noted, Geopark networks such as the Asian Geoparks Network and the European Geoparks Network are "providing models for engaging the public in the appreciation of geology that link sustainable economic development with preservation and interpretation of geology". Developing island-nations apparently have not been actively exploring geotourism assessments of geosites. Newsome et al. [29] identified the island of Mauritius as one of the few, if not the only, developing island-nation that has developed geotourism products since 2000. Several inlands in the Caribbean have the potential and opportunity to take the lead, embrace and introduce the geotourism concept to the region. Properly planned and managed geotourism is environmentally responsible, culturally responsible and synergistic [9]. Geotourism has the potential of further diversifying the region's tourism product and therefore should be embraced.

Product diversification and market segmentation in the tourism sector are critical in the Caribbean, given the fact that both the international tourism market as well as the demographics of the average tourist are changing. Today's travelers are more affluent, physically active, and better educated. They are more likely to base travel decisions on information obtained via the Internet to compare destinations, products, and costs. The region must therefore ensure that there is diversity in the tourism product and geotourism is one possible option for consideration. 


\section{Conclusions}

Whereas many of the islands of the Caribbean have marketed and promoted their destinations as 'nature tourism' and 'ecotourism' destinations in combination with the 'sea' sun' and 'sand' nostalgia, none of the islands has explicitly promoted geotourism as a component of the region's tourism products. Clearly, based on this exploratory scoping exercise and analysis, the region does have the basic resources and potential to support a coordinated, well defined, and integrated geotourism thrust.

Success in geotourism will require the building of regional support and coordination. Given the fact that these islands have limited expertise, and scarce marketing and promotion resources, it is strongly recommended that interested destinations should collaborate and coordinate their efforts either under the umbrella of the CTO or that of the OECS. The CTO should include geotourism as a discussion/presentation topic at its annual Sustainable Tourism Conferences in the future to help focus attention on this potentially socio-economically and socially viable sub-sector.

Geotourism assets, like any other component of the ecosystem, are subject to degradation from unmanaged and poorly planned use. Every effort will have to be made, therefore, to minimize ecological impacts and to protect the geotourism capital in the region. To be successful in this regard will call for coordinated regional initiatives and strategies, implemented simultaneously. Legislation and enforcement may be required in some circumstances. Environmental education of the local residents and visitors about the characteristics and fragility of these resources will have to be part of the mix.

Geotourism development in the Eastern Caribbean has received very little attention. It is anticipated that this paper will stimulate interest in geotourism at the sub-regional level as well as help to initiate discussion among Caribbean scientists, natural resource and tourism professionals about the region's geotourism assets and potential. This exploratory analysis has several limitations, including the fact that the analysis has been based primarily on literature review and personal knowledge. In order to develop a more data-driven approach in the long term, a questionnaire survey and possible face-to-face interviews of relevant Caribbean stakeholders is proposed. Such a survey will, among other things, help to identify the reasons and contributing factors why no destination in the Insular Caribbean has actively identified, developed, marketed and promoted geotourism as a component of the overall tourism product mix. Another activity which is deemed urgent and critical is the need for undertaking a comprehensive sub-regional inventory of potential geotourism sites. This inventory would serve as the initial framework on which to build an integrated regional geotourism destination including the establishment of geoparks in the region. Obviously, an integrated planning approach, the monitoring of environmental impacts and the geo-education of residents and visitors are critical dimensions which must be incorporated into any geotourism strategy and program for the region.

Funding: This research received no external funding.

Acknowledgments: The constructive comments of the reviewers are hereby acknowledged.

Conflicts of Interest: The author declares no conflict of interest.

\section{References}

1. CNN. Irma: A Hurricane for the History Books. 2017. Available online: https://www.cnn.com/specials / hurricane-irma (accessed on 9 January 2018).

2. Farsani, N.T.; Coelho, C.O.A.; Costa, C.M.M. Tourism Crisis Management in Geoparks through Geotourism Development. Rev. Tur. Desenvolv. 2018, 3, 1627-1638.

3. Christian, C.S.; Herbert, B. Perceived Socio-economic, Socio-ecological and Socio-cultural Impacts of the Caribbean Tourism Sector. Adv. Soc. Sci. Res. J. 2016, 3, 166-182.

4. Huang, R.; Sarigollu, E. Benefit Segmentation of Tourists to the Caribbean. J. Int. Consum. Mark. 2007, 19, 59-74. [CrossRef]

5. Caribbean Tourism Organization. Tourism Statistical Table, 2003-2015. Available online: http://www. onecaribbean.org/wp-content/uploads/Lattab2011UpdatedApril2013.pdf (accessed on 20 January 2018). 
6. UNWTO. Sustainable Development of Tourism-Definition. Available online: http://sdt.unwto.org/ content/about-us-5 (accessed on 9 January 2018).

7. Dowling, R. Geotourism. Available online: https://link.springer.com/content/pdf/10.1007/978-3-31901669-6_93-1.pdf (accessed on 9 January 2018).

8. Dowling, R.K. Geotourism's Global Growth. Geoheritage 2011, 3, 1-13. [CrossRef]

9. The National Geographic Society. Geotourism. Available online: https://www.nationalgeographic.com/ maps/geotourism/ (accessed on 9 January 2018).

10. Migon, P.; Pijet-Migon, E. Viewpoint geosites-Values, conservation and management issues. Proc. Geol. Assoc. 2017, 128, 511-522. [CrossRef]

11. Beard, J.S. The Natural Vegetation of the Windward and Leeward Islands-Oxford Forestry Memoirs No. 1; Oxford University Press: London, UK, 1949.

12. Evans, P.G.H.; James, A. Dominica Nature Island-Wildlife Checklist; Ministry of Tourism, Government of Dominica: Roseau, Dominica, 1997.

13. Seismic Research Centre. Programmes: The University of the West Indies at St. Augustine. Available online: http:/ / uwiseismic.com/Downloads/nevis4website.pdf (accessed on 20 January 2018).

14. Cumming, T.L.; Shackleton, R.T.; Forster, J.; Dini, J.; Khan, A.; Gumula, M.; Kubiszewski, I. Achieving the national development agenda and Sustainable Development Goals (SDGs) through investment in ecological infrastructure: A case study of South Africa. Ecosyst. Serv. 2017, 27, 253-260. [CrossRef]

15. Caribbean Volcanoes. The Geology of Dominica. 2015. Available online: http://caribbeanvolcanoes.com/ dominica-geology/ (accessed on 20 January 2018).

16. Lang, D.M. Soil and Land-Use Surveys, No. 21, Dominica; Regional Research Center, U.W.I.: Trinidad, 1967.

17. Ali, A. DOMNICA Nature Island of the Caribbean; Hansib Publishing Limited: London, UK, 1989.

18. UNESCO ${ }^{\mathrm{a}}$. Morne Trois Pitons National Park: World Heritage Centre. Available online: http://whc.unesco. org/en/list/814 (accessed on 9 January 2018).

19. Caribbean Disaster Mitigation Project (Cited as CDMP). Post-Disaster Response: Landslide Dam in the Layou River, Dominica. 1999. Available online: http://www.oas.org/cdmp/bulletin/layou.htm (accessed on 21 January 2018).

20. Odabasi, E.; Turan, M.; Erdem, H.; Tekbas, F. Does Mud Treatment have any Chemical Effect? A Randomized Control Clinical Study. J. Altern. Complement. Med. 2008, 14, 559-565. [CrossRef] [PubMed]

21. Blahna, D.J.; Asah, S.T.; Deal, R.L. An Ecosystem Services Framework. In People, Forests, and Change; Olson, D.H., Van Horne, B., Eds.; Island Press: Washington, DC, USA, 2017.

22. Evans, P.G.H.; James, A. Dominica Nature Island-A Guide to Nature Sites; Ministry of Tourism, Government of Dominica: Roseau, Dominica, 1997.

23. Evans, P.G.H. Dominica Nature Island-A Guide to Dive Sites and Marine Life; Ministry of Tourism, Government of Dominica: Roseau, Dominica, 1997.

24. UNESCO. First Wave of New Properties Added to World Heritage List for 2004. 2004. Available online: http:/ / whc.unesco.org/en/news/65/ (accessed on 10 February 2018).

25. Finkelman, R.B. Health Benefits of Geological Materials and Geological Processes. Int. J. Environ. Res. Public Health 2006, 3, 338-342. [CrossRef] [PubMed]

26. EBusiness. The Basic of Branding. Available online: https://www.entrepreneur.com/article/77408 (accessed on 9 January 2018).

27. UNESCO. What Is a UNESCO Global Geopark? 2017. Available online: http://www.unesco.org/new / en/natural-sciences / environment/earth-sciences/unesco-global-geoparks / frequently-asked-questions / what-is-a-unesco-global-geopark/ (accessed on 9 January 2018).

28. Miller, R.; Bremner, G.; Wilson, L. Geoheritage and Geotourism in Stonehammer Geopark: North America's First Global Geopark. Geosci. Can. 2013, 40, 363-364. [CrossRef]

29. Newsome, D.; Dowling, R.; Leung, Y.-F. The nature and management of geotourism: A case study of two established iconic geotourism destinations. Tour. Manag. Perspect. 2012, 2, 19-27. [CrossRef]

(C) 2018 by the author. Licensee MDPI, Basel, Switzerland. This article is an open access article distributed under the terms and conditions of the Creative Commons Attribution (CC BY) license (http:/ / creativecommons.org/licenses/by/4.0/). 